\title{
The Effect of Grape Marc and Olive Pomace Organic Wastes on Nutrition of Kalecik Karası and Narince (Vitis vinifera L.) Grape Varieties
}

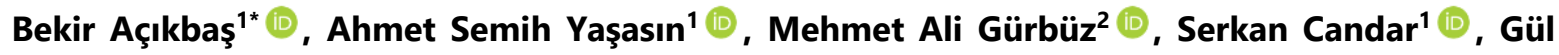 \\ Aras-Çınar ${ }^{3}$ (I) \\ ${ }^{1}$ Viticulture Research Institute, Tekirdağ, Turkey. \\ ${ }^{2}$ Atatürk Soil and Water Agricultural Meteorology Research Institute, Kırklareli, Turkey. \\ ${ }^{3}$ District Directorate of Agriculture of Konyaaltı, Antalya, Turkey
}

How to cite: Açıkbaş, B., Yaşasın, A. S., Gürbüz, M. A., Candar, S., \& Aras-Çınar, G. (2021). The effect of grape marc and olive pomace organic wastes on nutrition of Kalecik Karası and Narince (Vitis vinifera L.) grape varieties. Viticulture Studies (VIS), $2(1): 25$ - 32. https://doi.org/10.52001/vis.2022.8.25.32

Article History:

Received: 15.12 .2021

Accepted: 13.01.2022

First online: 14.01.2022

\section{Corresponding Author}

bekir.acikbas@tarimorman.gov.tr

\author{
Keywords \\ Organic fertilizer \\ Organic material \\ Grape nutrition \\ Sustainability \\ Agricultural residues
}

\section{Introduction}

As a result of harvesting agricultural products and processing them into foodstuffs, a significant amount of organic matter source waste material is generated. With the increase in the amount of agricultural production, harvest residues and agricultural industry residues increase (Baran et al., 1995). Increasing productivity in the agricultural sector, protecting the environment, and evaluating the resulting organic waste cycle reveal the sustainability and importance of soil quality (Koç et al., 2021). Organic wastes have the potential to be a source of plant nutrients and organic matter that can be used in the nutrition of plants. Organic wastes are materials with high organic fertilizer potential in viticulture due to their effects on soil properties and vine nutrition in terms of organic matter and plant nutrients they contain (Çıtak et al., 2006).

On the other hand, the use of organic waste materials in agricultural areas has become more prominent in recent years due to the increasing energy need for the production of chemical fertilizers, the cost factors associated with alternative waste management methods, and environmental problems (Çetin, 2002).

Grape marc is the waste material released as a result of processing grape into wine. Grape marc, which consists of $17-20 \%$ of the grape berry (Çıtak et al., 2006), contains the skin, pulp and seeds, is used as animal feed and fertilizer in Turkey. It has been reported that grape pomace contains $84.2 \%$ organic matter, $47 \%$ organic carbon, $2.4 \% \mathrm{~N}, 0.22 \% \mathrm{P}$ and $3.25 \% \mathrm{~K}$ (Baran et al., 1995).

Olive pomace is the solid waste product left 
over from processing olives into olive oil. An average of $35-45 \mathrm{~kg}$ pomace is obtained from $100 \mathrm{~kg}$ of mechanically processed olives (Öcal, 2005). Olive pomace contains $84.9-97.6 \%$ organic matter, $49.5 \%-53.9 \%$ total organic carbon, $0.7-1.84 \%$ total $\mathrm{N}, 0.07-0.22 \% \mathrm{P}$ and 0.77-2.97\% K (Deliboran et al., 2020).

One of the reasons for the study is that there are publications reporting that the organic matter of the soils in the Thrace Region, where the research was carried out, is generally low (Bellitürk et al., 2009; Gürbüz and Kardeş, 2014). Due to the importance of organic matter in plant nutrition, the value of organic wastes is increasing.

In this research, the effects of grape marc and olive pomace on the nutrition of cv. Kalecik Karası and cv. Narince (Vitis vinifera L.) wine grape varieties were investigated as a result of the application of certain doses to the vineyard soil.

\section{Material and Methods}

Vineyard, Organic Material Analysis, Soil Conditions and Experimental Design

The experiment was conducted during the 2014-2017 years on cv. Kalecik Karası and cv. Narince grapevines (Vitis vinifera L.) onto Kober $5 B B$ in the coordinates $40^{\circ} 58^{\prime} \mathrm{N}$.- $27^{\circ} 28^{\prime} \mathrm{E}$, in Tekirdağ, Turkey.

Kalecik Karası vineyard was established in 1997 with vine spacing of 2.85 to $1.5 \mathrm{~m}$ and Narince vineyard was established in 1998 with 2.5 to $1.5 \mathrm{~m}$ of vine. Kalecik Karası variety was cultivated with Cordon Royat where Narince variety was cultivated with Guyot pruning form.

Soil samples and organic material samples were analyzed in Kırklareli Atatürk Soil and Water Agricultural Meteorology Research Institute laboratory. Total $\mathrm{N}$ was obtained by Kjeldahl distillation method, and other nutriton elements in the samples were detected in Spectro Arcos SOP ICP-OES (Inductively Coupled Plasma) device. Organic materials analysis; $\mathrm{pH}$ and EC values 1:2.5 organic matter: distilled water mixture (Richards, 1954), organic matter by dry burning method (Nelson and Sommers, 1982), organic carbon calculating from organic matter (Tüzüner, 1990); total $\mathrm{N}$ modified Kjeldahl, $\mathrm{P}$ was determined by wet burning with nitric-perchloric acid and yellow color method, and $\mathrm{K}, \mathrm{Ca}, \mathrm{Mg}, \mathrm{S}$, $\mathrm{Na}, \mathrm{Fe}, \mathrm{Zn}, \mathrm{Mn}, \mathrm{Cu}$ and $\mathrm{Al}$ were detected in ICPOES (Kacar, 2012). Soil analysis; pH and EC in saturated paste (Richards, 1954), soil lime with Scheibler calcimeter (Tüzüner, 1990), organic matter modified Walkley Black method (Nelson and Sommers, 1982), available phosphorus by Olsen et al., (1954), extractable K, Ca and Mg (ammonium acetate extraction methods) and available $\mathrm{Fe}, \mathrm{Cu}, \mathrm{Zn}, \mathrm{Mn}$ (DTPA extraction methods) were determined in ICP-OES device (Lindsay and Norwell, 1978; Kacar, 2012).

The results of the chemical analysis on the organic materials of grape marc and olive pomace are given in Table 1 and Table 2 .

Grape marc (GM) and olive pomace (OP) were applied to the soil once in 2014 as industrial waste, without being processed.

- In TF 1 application no chemical and organic fertilizers were applied.

-In $\mathrm{TF}_{2}$ application standard chemical fertilizer according to Güçdemir and Usul (2004) and no

Table 1. Chemical analysis results of organic materials

\begin{tabular}{cccccccccc}
\hline $\begin{array}{c}\text { Organic } \\
\text { matter }\end{array}$ & $\begin{array}{c}\mathrm{pH} \\
(1 / 2.5)\end{array}$ & $\begin{array}{c}\mathrm{EC} \\
\left(\mathrm{ds} \mathrm{m}^{-1}\right)\end{array}$ & $\begin{array}{c}\text { Organic } \\
\text { matter, }(\%)\end{array}$ & $\begin{array}{c}\mathrm{C}, \\
(\%)\end{array}$ & $\begin{array}{c}\mathrm{N}, \\
(\%)\end{array}$ & $\begin{array}{c}\mathrm{C} / \mathrm{N} \\
\text { ratio }\end{array}$ & $\begin{array}{c}\mathrm{P}_{\mathrm{I}} \\
\left(\mathrm{mg} \mathrm{kg}^{-1}\right)\end{array}$ & $\begin{array}{c}\mathrm{K}_{\mathrm{I}} \\
\left(\mathrm{mg} \mathrm{kg}^{-1}\right)\end{array}$ & $\begin{array}{c}\mathrm{Ca}, \\
\left(\mathrm{mg} \mathrm{kg}^{-1}\right)\end{array}$ \\
\hline Grape marc & 7.10 & 3.30 & 40.50 & 23.57 & 1.10 & 21.43 & 2287.20 & 8195.40 & 4175.40 \\
\hline Olive pomace & 4.04 & 3.10 & 37.10 & 21.55 & 0.70 & 30.78 & 926.50 & 8963.50 & 1461.00 \\
\hline
\end{tabular}

Table 2. Chemical analysis results of organic materials (continued)

\begin{tabular}{ccccccccc}
\hline $\begin{array}{c}\text { Organic } \\
\text { matter }\end{array}$ & $\begin{array}{c}\mathrm{Mg}, \\
\left(\mathrm{mg} \mathrm{kg}^{-1}\right)\end{array}$ & $\begin{array}{c}\mathrm{S}, \\
\left(\mathrm{mg} \mathrm{kg}^{-1}\right)\end{array}$ & $\begin{array}{c}\mathrm{Fe}, \\
\left(\mathrm{mg} \mathrm{kg}^{-1}\right)\end{array}$ & $\begin{array}{c}\mathrm{Mn}, \\
\left(\mathrm{mg} \mathrm{kg}^{-1}\right)\end{array}$ & $\begin{array}{c}\mathrm{Zn}, \\
\left(\mathrm{mg} \mathrm{kg}^{-1}\right)\end{array}$ & $\begin{array}{c}\mathrm{B}, \\
\left(\mathrm{mg} \mathrm{kg}^{-1}\right)\end{array}$ & $\begin{array}{c}\mathrm{Na}, \\
\left(\mathrm{mg} \mathrm{kg}^{-1}\right)\end{array}$ & $\begin{array}{c}\mathrm{Al}, \\
\left(\mathrm{mg} \mathrm{kg}^{-1}\right)\end{array}$ \\
\hline Grape marc & 852.70 & 1329.90 & 113.90 & 19.90 & 12.90 & 22.10 & 17.60 & 244.30 \\
\hline Olive pomace & 591.60 & 947.90 & 195.90 & 8.60 & 5.60 & 15.70 & 12.90 & 114.40 \\
\hline
\end{tabular}


organic fertilizer was applied.

- $G M_{1}, G_{2}, G M_{3}$ applications were respectively 10 ton ha ${ }^{-1}, 20$ ton ha ${ }^{-1}$ and 40 ton ha- doses of grape marc with no chemical fertilizer.

$-\mathrm{OP}_{1}, \mathrm{OP}_{2}, \mathrm{OP}_{3}$ applications were respectively 10 ton ha- ${ }^{-1}, 20$ ton ha-1 and 40 ton ha-1 doses of olive pomace with no chemical fertilizer.

The experimental design was a completely randomized blocks design with each treatment comprising 3 replications and 2 vines for each replication.

\section{Climate Data}

Descriptive meso-climatic weather data such as temperature and total precipitation were derived from MEVBIS (Meteorological Data Information Presentation and Sales System) for the period 1939-2017 and for the experimental years.

\section{Plant Material}

Kalecik Karası and Narince (Vitis vinifera L.) varieties, which are important autochthonous wine grape varieties of Turkey, were used as plant material.

Kalecik Karası is one of Turkey's oldest and prestigious wine grapes. The variety has been cultivated in the central Anatolia region since the Hittites era (Carbonneau et al., 2021). Kalecik Karası variety has round, black-blue colored and thick-skin berries. The cluster is winged-conical, small-medium sized and dense (Çelik, 2006). Violet-ruby colored wine is flavoured, full and balanced. The most typical flavors of the variety, which has weak tannins but rich in fruit flavors, are cotton candy, strawberry and raspberry (Candar et al., 2021).

Narince is one of the important varieties of Turkey for white wine production, which is also produced as table and stuffed grape. The grape variety is originated in Tokat region. Tokat and its region are the transition point of the continental climate to Black Sea climate (Carbonneau et al., 2021). Narince is also adapted to Southern Thrace, Çanakkale and Northern Aegean, which are approximately at the same latitude as around origin location Tokat (Candar et al., 2021).

The berry is yellow in color, slightly oval shaped, medium 3-4 gr in size. The cluster is branched-conical in shape, large in size (Çelik, 2006). Semi-dry wines with their special aroma is produced from Narince grape variety (Candar et al., 2021).

\section{Analysis of Nutrients in the Leaf}

Leaf samples were taken from the whole leaf opposite the first cluster at verasion (Robinson, 1978). Random samples of 24 leaves from two vines from each replication were taken to the laboratory in plastic bags. Leaves were firstly passed in tap water and distilled water. Then dried the air in the shade and at $65^{\circ} \mathrm{C}$ in a laboratory oven until the weight loss ends (Kacar, 2014). The dried samples were grinded and prepared for analysis (Benito et al., 2013). Total nitrogen $(\mathrm{N})$ was obtained by the modified Kjeldahl method (Anton Paar Wave Go). P, K, Ca, $\mathrm{Mg}, \mathrm{Fe}, \mathrm{Cu}, \mathrm{Zn}, \mathrm{Mn}$ and $\mathrm{B}$ analyses were carried out with wet burning method (nitric-perchloric acid mixture) and then with Inductively Coupled Plasma Atomic Emission Spectrophometer (Spectro Arcos SOP) device (Kacar, 2014). The sufficiency ranges (Jones et al., 1991) used in the evaluation of the obtained leaf analysis results are given in Table 3.

\section{Trial Design and Statistical Analyzes}

$\mathrm{JMP}^{\odot}$ 13.2.0 (SAS Institute, Inc.) statistical program was used to perform statistical data

Table 3. Sufficiency ranges of grape leaf nutrients

\begin{tabular}{|c|c|c|c|}
\hline Nutrient & Deficient & Adequate & Excessive \\
\hline $\mathrm{N}(\%)$ & $1.50-1.99$ & $2.00-2.40$ & $>2.40$ \\
\hline $\mathrm{P}(\%)$ & $0.22-0.29$ & $0.30-0.40$ & $>0.40$ \\
\hline K (\%) & $1.00-1.29$ & $1.30-1.40$ & $>1.40$ \\
\hline $\mathrm{Fe}\left(\mathrm{mg} \mathrm{kg}^{-1}\right)$ & $50.00-59.00$ & $60.00-175.00$ & $>175.00$ \\
\hline $\mathrm{Cu}\left(\mathrm{mg} \mathrm{kg}^{-1}\right)$ & $3.00-4.00$ & $5.00-50.00$ & $>50.00$ \\
\hline $\mathrm{Zn}\left(\mathrm{mg} \mathrm{kg}^{-1}\right)$ & $18.00-24.00$ & $25.00-100.00$ & $>100.00$ \\
\hline $\mathrm{Mn}\left(\mathrm{mg} \mathrm{kg}^{-1}\right)$ & $25.00-29.00$ & $30.00-300.00$ & $>300.00$ \\
\hline
\end{tabular}


analysis. The significance of the differences between treatments was determined using oneway analysis of variance (ANOVA) and significant differences were grouped with the LSD test at $5 \%$ significance level.

\section{Results and Discussion}

\section{Climate}

In the research area, the average temperature for the 1939-2017 period has been determined as $14.0{ }^{\circ} \mathrm{C}$. The average temperatures for 2015, 2016, and 2017 were recorded as high as $14.7,15.1$ and $14.5{ }^{\circ} \mathrm{C}$ respectively. The average total precipitation for the period of 1939-2017 was determined as $581.8 \mathrm{~mm}$. The averages of 2015, 2016 and 2017 were recorded in variable amounts such as 549.2, 477.2, and $430.1 \mathrm{~mm}$ respectively. In terms of total precipitation, it is understood that precipitation is lower than the average of long years in all experimental years, with lower precipitation in 2016 and 2017.

\section{Organic Material and Soil Conditions}

In the analysis results of the organic materials, it was determined that the organic matter and plant nutrient contents were high. Especially grape marc organic material has higher contents in terms of $\mathrm{P}$ and $\mathrm{Ca}$. Also, olive pomace has a lower $\mathrm{pH}$ than grape marc (Table 1 and Table 2).

According to the results of soil analysis made in both vineyard soils (Table 4); $\mathrm{pH}$ is slightly alkaline, salinity is low and calcification is found chalky. P content of organic matter content was found to be low (Anonymous, 2021). High levels of $\mathrm{K}, \mathrm{Ca}$ and $\mathrm{Mg}$ were detected. It has been determined that micronutrients are among the appropriate limit values (Sillanpaeae, 1990; Anonymous, 2021). The soils of both vineyards, which are the research material, are clay (C) and clay-loam (CL) soil texture.

\section{Grapevine Nutritional Status}

\section{Kalecik Karası Grape Variety}

As a result of leaf nutrient content analysis, the total $\mathrm{N}$ content of Kalecik Karası variety was determined within sufficient ranges in 2015. But in 2016 and 2017, according to Jones et al. (1991), leaf total $\mathrm{N}$ amount was determined to be insufficient for all applications (Table 5). Although the P content was generally insufficient in experimental years, it was found to be higher and close to the limit in year of 2017. $\mathrm{K}$ contents in grapevine varieties were generally found to be insufficient in terms of expected limits.

Macronutrients, except $\mathrm{N}$ reached higher values in the second year of the experiment. This situation possibly resulted from the increasing root amount of the plants in the second year and the plant nutrients that started to accumulate in the increasing perennial parts. Leaf macro element results determined in Kalecik Karası grape variety are largely similar to Erdoğan (2010). In particular, similar values were obtained for leaf $\mathrm{P}$ and $\mathrm{K}$ contents (Table 5 ).

Table 4. Physical and chemical characteristics of the vineyard experimental soil

\begin{tabular}{lcccc}
\hline \multirow{2}{*}{ Soil parameters } & \multicolumn{2}{c}{ Narince Cultivar Soil Depth $(\mathrm{cm})$} & \multicolumn{2}{c}{ Kalecik Karası Cultivar Soil Depth (cm) } \\
\cline { 2 - 5 } & $0-20$ & $20-40$ & $0-20$ & $20-40$ \\
\hline $\mathrm{pH}$ (saturation) & 7.35 & 7.15 & 7.75 & 7.72 \\
\hline Soluable salt (\%) & 0.06 & 0.04 & 0.06 & 0.06 \\
\hline Lime content $\left(\mathrm{CaCO}_{3,} \%\right)$ & 1.00 & 1.00 & 3.17 & 3.50 \\
\hline Organic matter $(\%)$ & 0.84 & 0.83 & 0.99 & 1.27 \\
\hline $\mathrm{P}_{2} \mathrm{O}_{5}\left(\mathrm{~kg} \mathrm{da}^{-1}\right)$ & 3.86 & 1.90 & 1.52 & 102.7 \\
\hline $\mathrm{K}_{2} \mathrm{O}\left(\mathrm{kg} \mathrm{da}^{-1}\right)$ & 60.0 & 85.1 & 80.6 & 7182.0 \\
\hline $\mathrm{Ca}\left(\mathrm{mg} \mathrm{kg}^{-1}\right)$ & 5640.7 & 5386.1 & 7568.3 & 342.3 \\
\hline $\mathrm{Mg}\left(\mathrm{mg} \mathrm{kg}^{-1}\right)$ & 390.0 & 397.9 & 294.0 & 5.40 \\
\hline $\mathrm{Fe}\left(\mathrm{mg} \mathrm{kg}^{-1}\right)$ & 4.99 & 5.08 & 5.07 & 7.50 \\
\hline $\mathrm{Cu}\left(\mathrm{mg} \mathrm{kg}^{-1}\right)$ & 16.83 & 14.50 & 8.74 & 0.63 \\
\hline $\mathrm{Zn}\left(\mathrm{mg} \mathrm{kg}^{-1}\right)$ & 1.80 & 1.50 & 1.01 & 1.48 \\
\hline $\mathrm{Mn}\left(\mathrm{mg} \mathrm{kg}^{-1}\right)$ & 3.62 & 3.35 & 1.14 & \\
\hline
\end{tabular}


Table 5. Effect of organic material applications on Kalecik Karası grape cultivar leaves concentrations

\begin{tabular}{|c|c|c|c|c|c|c|c|c|c|}
\hline \multirow[t]{2}{*}{ App. } & \multicolumn{3}{|c|}{$\begin{array}{c}\mathbf{N} \\
(\%)\end{array}$} & \multicolumn{3}{|c|}{$\begin{array}{c}\mathbf{P} \\
(\%)\end{array}$} & \multicolumn{3}{|c|}{$\begin{array}{c}\mathbf{K} \\
(\%)\end{array}$} \\
\hline & 2015 & 2016 & 2017 & 2015 & 2016 & 2017 & 2015 & 2016 & 2017 \\
\hline$\overline{\mathrm{TF}_{1}}$ & 1.99 & 1.84 & 1.93 & 0.08 & 0.11 & 0.22 & 0.58 & 0.72 & 1.14 \\
\hline $\mathrm{TF}_{2}$ & 2.08 & 1.92 & 1.90 & 0.08 & 0.11 & 0.21 & 0.64 & 0.80 & 0.90 \\
\hline $\mathrm{GM}_{1}$ & 2.00 & 1.82 & 1.60 & 0.08 & 0.12 & 0.22 & 0.62 & 0.72 & 1.12 \\
\hline $\mathrm{GM}_{2}$ & 1.95 & 1.70 & 1.77 & 0.06 & 0.10 & 0.20 & 0.52 & 0.77 & 1.23 \\
\hline $\mathrm{GM}_{3}$ & 2.11 & 1.95 & 1.77 & 0.08 & 0.12 & 0.21 & 0.58 & 0.84 & 0.74 \\
\hline $\mathrm{OP}_{1}$ & 2.05 & 1.91 & 1.87 & 0.07 & 0.11 & 0.22 & 0.54 & 1.03 & 1.12 \\
\hline $\mathrm{OP}_{2}$ & 1.96 & 1.74 & 1.60 & 0.08 & 0.11 & 0.23 & 0.69 & 0.73 & 1.31 \\
\hline $\mathrm{OP}_{3}$ & 2.11 & 1.80 & 1.87 & 0.07 & 0.12 & 0.20 & 0.45 & 0.73 & 0.91 \\
\hline Mean & 2.03 & 1.84 & 1.79 & 0.08 & 0.11 & 0.21 & 0.58 & 0.79 & 1.06 \\
\hline $\operatorname{LSD}_{0,05}$ & 0.418 & 0.328 & 0.140 & 0.082 & 0.181 & 0.768 & 0.281 & 0.375 & 0.392 \\
\hline
\end{tabular}

TF; Traditional fertilizer. GM; Grape marc. OP; Olive pomace. App.; Application.

*The values with different letters in a column are significantly different $(p<0.05)$ with LSD test of the data.

Table 6. Effect of organic material applications on Kalecik Karası grape cultivar leaves concentrations

\begin{tabular}{|c|c|c|c|c|c|c|c|c|c|c|c|c|}
\hline \multirow[t]{2}{*}{ App. } & \multicolumn{3}{|c|}{$\begin{array}{c}\mathbf{F e} \\
\left(\mathrm{mg} \mathrm{kg}^{-1}\right)\end{array}$} & \multicolumn{3}{|c|}{$\begin{array}{c}\mathbf{C u} \\
\left(\mathrm{mg} \mathrm{kg}^{-1}\right)\end{array}$} & \multicolumn{3}{|c|}{$\begin{array}{c}\mathbf{Z n} \\
\left(\mathrm{mg} \mathrm{kg}^{-1}\right)\end{array}$} & \multicolumn{3}{|c|}{$\begin{array}{c}\mathbf{M n} \\
\left(\mathrm{mg} \mathrm{kg}^{-1}\right)\end{array}$} \\
\hline & 2015 & 2016 & 2017 & 2015 & 2016 & 2017 & 2015 & 2016 & 2017 & 2015 & 2016 & 2017 \\
\hline $\mathrm{TF}_{1}$ & 287.1 & 168.4 & 425.4 & 40.5 & 9.0 & 282.3 & 16.4 & 57.2 & 53.6 & 56.3 & 42.4 & 138.7 \\
\hline $\mathrm{TF}_{2}$ & 69.9 & 178.9 & 271.2 & 280.1 & 9.5 & 273.3 & 15.2 & 63.4 & 55.5 & 49.9 & 48.3 & 92.9 \\
\hline $\mathrm{GM}_{1}$ & 244.5 & 175.2 & 558.3 & 150.0 & 9.6 & 375.6 & 41.8 & 60.0 & 58.8 & 47.4 & 39.7 & 101.2 \\
\hline $\mathrm{GM}_{2}$ & 332.5 & 146.3 & 285.6 & 123.2 & 9.7 & 673.8 & 44.0 & 77.3 & 52.1 & 44.1 & 51.7 & 81.7 \\
\hline $\mathrm{GM}_{3}$ & 136.9 & 159.2 & 480.5 & 168.8 & 10.4 & 478.6 & 32.3 & 45.5 & 44.3 & 45.1 & 47.4 & 90.0 \\
\hline $\mathrm{OP}_{1}$ & 98.8 & 158.6 & 764.1 & 77.1 & 9.7 & 373.2 & 22.5 & 54.8 & 58.8 & 46.4 & 32.0 & 104.8 \\
\hline $\mathrm{OP}_{2}$ & 300.4 & 163.8 & 493.3 & 73.0 & 9.1 & 447.1 & 40.5 & 48.6 & 55.1 & 45.8 & 40.9 & 156.6 \\
\hline $\mathrm{OP}_{3}$ & 499.5 & 148.7 & 398.8 & 174.9 & 10.1 & 458.1 & 26.8 & 107.3 & 47.3 & 45.1 & 33.1 & 113.8 \\
\hline Mean & 246.20 & 162.40 & 359.60 & 136.00 & 9.60 & 420.30 & 25.00 & 64.30 & 53.20 & 47.50 & 41.90 & 110.00 \\
\hline $\mathrm{LSD}_{0,05}$ & 0.509 & 0.406 & 0.303 & 0.195 & 0.808 & 0.315 & 0.133 & 0.384 & 0.331 & 0.456 & 0.789 & 0.367 \\
\hline
\end{tabular}

TF; Traditional fertilizer. GM; Grape marc. OP; Olive pomace. App.; Application.

*The values with different letters in a column are significantly different $(p<0.05)$ with LSD test of the data.

Micronutrients Fe and $\mathrm{Cu}$ contents were at sufficient levels in 2016, while in other years, they were above the limit values and in a high values (Table 6). The high Fe contents obtained are similar to studies such as Yener (2002), and it is considered that healthy results are not obtained. In terms of $\mathrm{Cu}$ content, it is thought that high values are obtained due to the preparations applied to fungal diseases on vines. It has been reported that the plant samples may have copper-containing pesticides residues (Kacar, 2014).

$\mathrm{TF}_{1}, \mathrm{TF}_{2}$ and $\mathrm{OP}_{1}$ applications, $\mathrm{Zn}$ contents were found to be insufficient in 2015, but other years and applications were found to be sufficient in terms of $\mathrm{Zn}$ contents. It was determined that $\mathrm{Mn}$ contents were sufficient in all applications during experimental years (Table 6).

\section{Narince Grape Variety}

The total $\mathrm{N}$ content of the Narince grape variety leaf analysis results were found sufficient in 2015 and 2017, and also were found lower than the limit value in 2016. It has been determined that the P contents in Narince grape variety were generally insufficient, as in the Kalecik Karası grape variety, and reached values close to the limit in 2017. K contents were determined below the limit value in 2015 and 2016. In 2017, it was determined at sufficient levels in $\mathrm{TF}_{2}$ and grape marc and olive pomace applications (Table 7). There were no significant differences between the applications in terms of macronutrients.

Narince grape variety leaf $\mathrm{P}$ and $\mathrm{K}$ contents results consider to be compatible with previous studies (Kılıç, 2007). 
Table 7. Effect of organic material applications on Narince grape cultivar leaves concentrations

\begin{tabular}{|c|c|c|c|c|c|c|c|c|c|}
\hline \multirow[t]{2}{*}{ App. } & \multicolumn{3}{|c|}{$\begin{array}{c}\mathbf{N} \\
(\%)\end{array}$} & \multicolumn{3}{|c|}{$\begin{array}{c}\mathbf{P} \\
(\%)\end{array}$} & \multicolumn{3}{|c|}{$\begin{array}{c}\mathbf{K} \\
(\%)\end{array}$} \\
\hline & 2015 & 2016 & 2017 & 2015 & 2016 & 2017 & 2015 & 2016 & 2017 \\
\hline $\mathrm{TF}_{1}$ & 2.06 & 1.81 & 1.83 & 0.09 & 0.13 & 0.24 & 0.61 & 0.73 & 1.41 \\
\hline $\mathrm{TF}_{2}$ & 2.19 & 1.81 & 2.23 & 0.09 & 0.13 & 0.27 & 0.65 & 0.89 & 1.03 \\
\hline $\mathrm{GM}_{1}$ & 2.00 & 2.00 & 2.30 & 0.10 & 0.13 & 0.27 & 0.83 & 0.89 & 1.14 \\
\hline $\mathrm{GM}_{2}$ & 2.13 & 1.93 & 2.13 & 0.10 & 0.13 & 0.28 & 0.70 & 0.78 & 1.63 \\
\hline $\mathrm{GM}_{3}$ & 2.19 & 1.80 & 2.03 & 0.10 & 0.14 & 0.26 & 0.69 & 0.79 & 0.90 \\
\hline $\mathrm{OP}_{1}$ & 2.16 & 1.93 & 2.00 & 0.10 & 0.12 & 0.24 & 0.60 & 0.67 & 1.33 \\
\hline $\mathrm{OP}_{2}$ & 2.03 & 1.75 & 2.03 & 0.20 & 0.13 & 0.26 & 0.66 & 0.74 & 1.40 \\
\hline $\mathrm{OP}_{3}$ & 2.17 & 1.85 & 1.97 & 0.09 & 0.14 & 0.25 & 0.72 & 0.84 & 1.09 \\
\hline Mean & 2.12 & 1.86 & 2.07 & 0.11 & 0.13 & 0.26 & 0.68 & 0.79 & 1.24 \\
\hline $\mathrm{LSD}_{0,05}$ & 0.503 & 0.797 & 0.175 & 0.407 & 0.082 & 0.688 & 0.799 & 0.304 & 0.442 \\
\hline
\end{tabular}

TF; Traditional fertilizer. GM; Grape marc. OP; Olive pomace. App.; Application.

*The values with different letters in a column are significantly different $(p<0.05)$ with LSD test of the data.

Table 8. Effect of organic material applications on Narince grape cultivar leaves concentrations

\begin{tabular}{|c|c|c|c|c|c|c|c|c|c|c|c|c|}
\hline \multirow[t]{2}{*}{ App. } & \multicolumn{3}{|c|}{$\begin{array}{c}\mathbf{F e} \\
\left(\mathrm{mg} \mathrm{kg}^{-1}\right)\end{array}$} & \multicolumn{3}{|c|}{$\begin{array}{c}\mathbf{C u} \\
\left(\mathrm{mg} \mathrm{kg}^{-1}\right)\end{array}$} & \multicolumn{3}{|c|}{$\begin{array}{c}\mathbf{Z n} \\
\left(\mathrm{mg} \mathrm{kg}^{-1}\right)\end{array}$} & \multicolumn{3}{|c|}{$\begin{array}{c}\mathbf{M n} \\
\left(\mathrm{mg} \mathrm{kg}^{-1}\right)\end{array}$} \\
\hline & 2015 & 2016 & 2017 & 2015 & 2016 & 2017 & 2015 & 2016 & 2017 & 2015 & 2016 & 2017 \\
\hline $\mathrm{TF}_{1}$ & 253.9 & 156.7 & $425.4 \mathrm{c}$ & 330.0 & $7.6 \mathrm{abc}$ & 282.3 & 25.7 & 53.8 & 49.5 & 114.8 & $131.7 \mathrm{abc}$ & 190.5 \\
\hline $\mathrm{TF}_{2}$ & 269.9 & 156.7 & $271.2 \mathrm{~d}$ & 88.3 & $7.7 \mathrm{abc}$ & 273.3 & 35.3 & 55.9 & 58.8 & 97.1 & 115.5 bc & 277.0 \\
\hline $\mathrm{GM}_{1}$ & 245.0 & 144.5 & $558.2 \mathrm{~b}$ & 120.3 & $8.3 a b$ & 375.6 & 20.6 & 74.0 & 41.6 & 113.9 & 166.7 a & 211.2 \\
\hline $\mathrm{GM}_{2}$ & 364.1 & 160.7 & $285.6 \mathrm{~d}$ & 128.3 & $8.6 \mathrm{a}$ & 673.8 & 24.3 & 56.3 & 55.1 & 140.9 & $146.8 \mathrm{ab}$ & 259.7 \\
\hline $\mathrm{GM}_{3}$ & 130.4 & 150.3 & $480.5 b c$ & 64.5 & $8.8 \mathrm{a}$ & 478.6 & 34.0 & 62.1 & 48.0 & 138.9 & $94.9 \mathrm{c}$ & 361.7 \\
\hline $\mathrm{OP}_{1}$ & 270.8 & 148.5 & $764.1 \mathrm{a}$ & 86.8 & $6.8 \mathrm{bc}$ & 373.2 & 31.1 & 57.9 & 51.9 & 94.0 & $98.9 \mathrm{c}$ & 258.9 \\
\hline $\mathrm{OP}_{2}$ & 393.8 & 141.5 & 493.3 bc & 242.4 & $7.4 a b c$ & 447.1 & 25.8 & 57.3 & 54.6 & 140.0 & $131.1 \mathrm{abc}$ & 376.8 \\
\hline $\mathrm{OP}_{3}$ & 344.4 & 112.9 & $398.8 \mathrm{c}$ & 74.7 & $6.5 c$ & 458.1 & 30.5 & 49.9 & 44.0 & 114.1 & $130.7 \mathrm{abc}$ & 238.4 \\
\hline Mean & 284.0 & 146.5 & 459.6 & 141.9 & 7.7 & 420.2 & 28.4 & 58.4 & 50.4 & 119.2 & 127.0 & 271.8 \\
\hline $\mathrm{LSD}_{0,05}$ & 0.451 & 0.096 & $0.001^{*}$ & 0.651 & $0.048 *$ & 0.291 & 0.954 & 0.125 & 0.362 & 0.789 & $0.022^{*}$ & 0.483 \\
\hline
\end{tabular}

TF; Traditional fertilizer. GM; Grape marc. OP; Olive pomace. App.; Application.

*The values with different letters in a column are significantly different $(p<0.05)$ with LSD test of the data.

In terms of micronutrient content, $\mathrm{Fe}$ and $\mathrm{Cu}$ contents were determined between the limit values in 2016. These microelements were detected above the limit values in years of 2015 and 2017. It was determined that the effects of organic waste applications on leaf $\mathrm{Cu}$ content were statistically significant in year 2016, GM 3 and $\mathrm{GM}_{2}$ applications formed the highest group statistically, while $\mathrm{OP}_{3}$ was formed the lowest. $\mathrm{Zn}$ and $\mathrm{Mn}$ contents were determined within the adequacy limits. Leaf $\mathrm{Mn}$ content differences were statistically significant and found highest in $\mathrm{GM}_{1}$ application in year 2016 and the lowest in $\mathrm{GM}_{3}$. The differences in leaf Fe contents were significant in 2017. $\mathrm{OP}_{1}$ treatment achieved the highest leaf Fe content, while GM2 represented the lowest leaf Fe content (Table 8).

The variation of $\mathrm{Fe}$ and $\mathrm{Cu}$ contents between years in Narince variety is similar to that in Kalecik Karası variety. The results obtained for
Fe contents for both grape varieties were at a high level, similar to the $212-717 \mathrm{mg} \mathrm{kg}^{-1}$ content found in Yuvarlak Çekirdeksiz grape variety by Yener et al. (2002).

There are no previous studies in which grape marc and olive pomace were used as organic sourced fertilizer in previous plant nutrition studies on grapevine plants.

However, in a previous study investigating the effects of pruning residue, farm manure, green manure and straw mulch organic materials on the nutrition of Çiloreş grape variety, it was reported that organic fertilizer and organic material applications caused significant increases in the uptake of macro and micro nutrients in grapevine plant (Özdemir et al., 2008). The carbohydrate reserves of perennial stem parts and roots and the delayed response of the vine plant to externally applied improvements to the vineyard soil may be the 
reasons for different results in this study. Tangolar et al. (2020) examined the effects of the application of different organic (compost, farm manure, pruning residue, straw and different mixtures) and inorganic materials in the vineyard soil on the nutrition of Black Magic grape variety, and reported that the addition of pumice in organic materials had a statistical effect. N, P, Ca, $\mathrm{Fe}$ and $\mathrm{Mn}$ contents for all applications were found within the limits of sufficiency; however, they reported that $\mathrm{K}, \mathrm{Mg}$ and $\mathrm{Zn}$ values were within the limits of deficiency. It is thought that the differences in results between the studies may also be due to the condition of the vineyard soil where the experiments conducted, the age of the grapevines and the cultivation processes in the past.

\section{Conclusion}

In this study, the effects of grape marc and olive pomace as organic sourced fertilizer on the nutrition status of Kalecik Karası and Narince grapevines were revealed for the first time. In view of the results presented herein, it is clear that organic waste applications do not generally differ in the nutrient content of both cultivars. But, it is also an important finding that organic wastes do not have negative effects on the nutrition of the grapevine in applications where chemical fertilizers are not applied to the vines during the experimental period. However, the longer-term effects of this phenomenon stand out as a subject that needs to be studied, especially with younger grapevines.
It is recommended to apply it together with chemical fertilizers and/or by composting in order to use organic wastes more effectively in the fertilization of grapevines.

\section{Acknowledgments}

The authors thank all editors, reviewers who read and contributed to the final version of the text.

\section{Funding}

This study was carried out under the project TAGEM/TSKAD/14/A13/P04/05, which was supported and funded by the General Directorate of Agricultural Research and Policies of the Republic of Turkey Ministry of Agriculture and Forestry.

\section{Author Contribution}

Authors ASY and GAÇ were planned and designed the trial. BA, ASY and SC performed the field experiments and made statistical analysis. MAG performed laboratory analyzes. BA, SC and MAG made critical revisions of the manuscript for intellectual content. All authors read and approved the final manuscript.

\section{Conflicts of Interest}

The authors declare that there is no conflict of interest.

\section{References}

Anonymous, (2021). Instructions on technical standards of land and soil classification (in Turkish). Republic of Turkey Ministry of Food Agriculture and Livestock. https://www.tarimorman.gov.tr/Belgeler/Mevzuat/Talimatlar/ToprakAraziSiniflamasiStandartlariTeknikTali mativellgiliMevzuat_yeni.pdf (Access: 01.11.2021)

Baran, A., Çaycı, G., \& İnal, A. (1995). Some physical and chemical properties of different agricultural wastes. Pamukkale University Journal of Engineering Sciences. 1(2-3), 169-172.

Bellitürk, K., Danışman, F., \& Sözübek, B. (2009). The relationship between mineralization capacities and physical and chemical properties of the soils in Tekirdag region/Turkey. Mediterranean Agricultural Sciences, 22(2), 141-147

Benito, A., Romero I., Domínguez N., Escudero E. G., Martín I. (2013). Leaf blade and petiole analysis for nutrient diagnosis in Vitis vinifera L. Cv. Garnacha tinta. Australian Journal of Grape and Wine Research, 19, 285298. https://doi.org/10.1111/ajgw.12022

Candar, S., Uysal, T., Ayaz, A., Akdemir, U., Korkutal, İ., \& Bahar, E. (2021). Viticulture tradition in Turkey. Viticulture Studies (VIS), 1(1), 39 - 54. https://doi.org/10.52001/vis.2021.5 
Carbonneau, A., Bahar, E., Candar, S., \& Alço, T. (2021). Le potentiel oenologique de cépages Turcs. Group of International Experts of Vitivinicultural Systems for CoOperation. https://doi.org/10.13140/RG.2.2.19399.21921

Çelik, H. (2006). Grape cultivar catalog. Sunfidan A.Ş. Mesleki Kitaplar Serisi:3, Ankara, p 165

Çetin, Ü. (2002). A research on the use of various organic wastes in agricultural soils (in Turkish with English abstract). Selçuk University Graduate School of Natural and Applied Sciences Department of Soil Science, MSc Thesis, Konya-Turkey.

Çıtak, S., Sönmez, S., \& Öktüren, F. (2006). The usage possibility of plant origin wastes in agriculture (in Turkish with English abstract). Derim Journal, 23(1), 40-53.

Deliboran, A., Savran, Ş., \& Kaya, Ü. (2020). Olive oil production wastes and evaluation methods (in Turkish with English abstract). Bahçe, 49 (Special ed.1), 257-269.

Erdoğan, E. (2010). Effects of cocktail mychorriza applications on vegetative development and product quality in Kalecik Karası winegrape variety grafted onto Kober 5BB (in Turkish with English abstract). Selçuk University Graduate School of Natural and Applied Sciences Department of Horticultural, MSc Thesis, Konya-Turkey.

Güçdemir, İ. H., \& Usul, M. (2004). Fertilizer recommendation in accordance with soil analysis. Turkey $3^{\text {rd }}$ National Fertilizer Congress, Agri-Industry-Environment, 11-13 October 2004, Tokat- Turkey.

Gürbüz, M. A., \& Kardeş, T. A. (2014). Determination of the nutritional status of wheat plant by plant and soil analysis in Thrace region. Turkish Journal of Agricultural and Natural Sciences Special Issue 1, 927-932

Jones, J. B., Wolf, Jr. B., \& Mills, H. A. (1991). Plant analysis handbook. Mikro-Makro Publishing Inc, USA. p 1-213

Kacar, B. (2012). Soil analysis (in Turkish, $3^{\text {rd }}$ ed.). Nobel Akademik Yayıncllık. No: 484, Ankara-Turkey. p 466. ISBN: 978-605-133-386-1

Kacar, B. (2014). Plant, soil and fertilizer analysis: 2 easy to apply plant analysis (in Turkish). Nobel Akademik Yayıncilık. No: 910, Ankara-Turkey. p 404 ISBN: 978-605-133-812-5

Kılıç, D. (2007). Effects of bud loading levels and different nitrogen doses on the yield and quality of brined vine leaves of Narince grape ( $V$. vinifera L.) cultivars (in Turkish with English abstract). Gaziosmanpaşa University Graduate School of Natural and Applied Sciences Department of Horticultural, MSc Thesis, Tokat-Turkey.

Koç, B., Bellitürk, K., Çelik, A., \& Baran, M. F. (2021). Effects of vermicompost and liquid biogas fertilizer application on plant nutrition of grapevine (Vitis vinifera L.). Erwerbs-Obstbau, 63(1), 89-100. https://doi.org/10.1007/s10341-021-00586-2

Lindsay, W. L., \& Norvell, W. A. (1978). Development of DTPA soil test for zinc, iron, manganese and copper. Soil Sci. Soc. Of America Journal, 42, 421-428.

Nelson, D. W., \& Sommers, L. E. (1982). Total carbon, organic carbon, and organic matter. In: Page, A. L., Keeney, D. R., Baker, D. E., Miller, R. H., Ellis, R., Rhoades, J. D. (Eds.), Methods of soil analysis part 2 (2 ${ }^{\text {nd }}$ edition). Chemical and microbiological properties. Agronomy Monograph No:9, 539-577, American Society of Agronomy, Inc. Soil Science Society of America, Inc. Madison, Wisconsin, USA ISBN 0-89118-072-9

Olsen, S. R., Cole, C. V., Watanale, F. S., \& Dean, L. A. (1954). Estimation of available phosphorus in soil by extraction with sodium bicarbonate. USDA Circular No: 939, Washington D.C.

Öcal, A. (2005). Investigation on using olive oil wastewater and prina for the purpose of plant growing (in Turkish with English abstract). Çukurova University Graduate School of Natural and Applied Sciences, MSc. Thesis, Adana-Turkey.

Özdemir, G., Tangolar, S., Gürsöz, S., \& Çakır, A. (2008). Effect of different organic manure applications on grapevine nutrient values. Asian Journal of Chemistry, 20(3), 1841-1847.

Richards, L. A. (1954). Diagnosis and improvement of saline and alkali soils. United States Department of Agriculture Handbook, p 60-94.

Robinson, J. A., Nicholas, P. R., \& McCarthy J. R. (1978). A comparison of three methods of tissue analysis for assessing the nutrient status of plantings of vitis vinifera in an irrigated area in South Australia. Australian Journal of Experimental Agriculture and Animal Husbandry, 18, 294-300.

Sillanpaeae, M. (1990). Micronutrient, assesment at the country level: An international study. FAO Soils Bulletin, 63.

Tangolar, S., Tangolar, S., Alkan Torun, A., \& Göçmez, S. (2020). Influence of supplementation of vineyard soil with organic substances on nutritional status, yield and quality of 'Black Magic' grape (Vitis vinifera L.) and soil microbiological and biochemical characteristics. OENO One, 54(4), 1143-1157. https://doi.org/10.20870/oeno-one.2020.54.4.4152

Tüzüner, A. (1990). Physical analysis methods of soils. In A. Tüzüner (Ed.) Soil and water analysis laboratories handbook (in Turkish), Ministry of Agriculture, Forestry and Rural Affairs General Directorate of Rural Services, Ankara-Turkey.

Yener, H., Aydın, Ş., \& Güleç, I. (2002). Nutrients status of Kavaklıdere Vineyards in Alaşehir Province (in Turkish with English abstract). Anadolu Journal of Aegean Agricultural Research Institute, 12(2), 110-138. 